\title{
A gépjárműiparban dolgozók motivációinak, munkatapasztalatának és határidőtartási szokásainak összefüggései a termékfejlesztési projektekben
}

\author{
SZENDI NIKOLETTA ${ }^{1}$
}

\begin{abstract}
ABSZTRAKT
Napjainkban számos új gépjármümodell fejlesztése történik a világ különböző részén található jármüipari vállalatoknál és beszállítóiknál. Az autóipari szegmensben a termék életciklus rövidülése és a globális piac hatása miatt az idôtényező kulcsszerepet játszik a projektek sikeres megvalósításában, és ezzel a termék értékesitésében. A jelen tanulmány az emberi tényezőre fókuszálva a projekttagok magatartását vizsgálja. Elsődleges célja nem az erőforrások hiányából, vagy a tervezés helytelenségéből adódó időveszteségek miatt bekövetkező hátráltató tényezôket feltárni. Az ilyen nyilvánvaló okok, veszélyek kimutatása és kezelése a projekt portfólió menedzsment testület hatáskörébe esik, ami jól müködik a nagyobb projektszervezetekben. A projekttagok egyéni módon viszonyulnak a határidők betartásához és a feladatok végrehajtásához kapcsoló motivációjuk is eltérō. A szakirodalomban fellelhető és általános kutatások eredményein túlmutatóan azt vizsgálom, hogy azonosítható-e az aktuális jármúipari szervezeti projektmunkában önálló jellegzetesség. A kutatás az autóipari fejlesztési projektben szerzett tapasztalat, motiváció és a határidők betartásának összefüggései alapján a munkavégzés hatékonyságát befolyásoló csoport (team) összetételt vizsgálja.
\end{abstract}

KULCSSZAVAK: autóipar, termékfejlesztési projekt, határidőtartás, motiváció, tapasztalat

\section{ABSTRACT}

The linkage between motivation, work experience and sense of deadline-keeping in product development projects of those working in the automotive industry

Nowadays, numerous new automobiles are being developed by various companies and their suppliers around the globe. On account of the reduction of the product's economic lifetime and effects of the global market, $n$ the automotive segments the time factor plays a key role in the successful implementation of the project and consequently in the sale of the product. The current study, focusing on human conditions, scrutinizes the behaviour of the members engaged in the

${ }^{1}$ PhD hallgató (PhD Student), Soproni Egyetem, Széchenyi István Doktori Iskola (University of Sopron, Faculty of Economics). 


\section{TEMATIKUS TANULMÁNYOK - Menedzsment: vezetók, vezetés és munkavállalók}

project. It's primary focus is not to reveal the hindering factors due to time-losses arising from the shortage of resources or inadequate planning. These conspicuous reasons and the demonstration as well as treatment of risk, belong to the scope of the board of project portfolio management, which operates well among larger project organizations. Each project member is taking an individual approach towards meeting deadlines, and their motivation about the execution of the given tasks also vary. Beyond the results found both in the professional literature as well as general research, I study whether the unique features of the actual automotive organizational projects can be identified or not. The ongoing research observes, based on the experience acquired from the automobile development project, motivation and adherence to deadlines, the composition of the team impacting work efficiency.

KEYWORDS: automotive industry, product development project, adherence to deadlines, motivation, experience

\section{Bevezetés}

Napjainkban számos új gépjárműmodell fejlesztése történik a világ különböző részén található járműipari vállalatoknál és beszállítóiknál. A módszerek és eljárások fejlődése, az erőeloszlás, áramlás és hőtani számítógépes szimulációk, a rapid prototyping olyan lehetőségeket adott a fejlesztők és tervezők kezébe, amelyekről azt gondolhatnánk, hogy a növekvő jármű-komplexitás ellenére is már-már könnyen kezelhetővé tesz egy termékfejlesztési projektet. A termékéletciklus rövidülése és a globális piac hatása miatt az időtényező kulcsszerepet játszik a projektek sikeres megvalósításában. Egyre gyorsuló ütemben jelennek meg innovációk, mint például az elektromos autók és a vezető nélküli rendszerek. A projektcsapatok a járműiparban a minőséget, a termékek paramétereit folyamatosan tökéletesítik.

Azonban nem csak sikerekről, hanem fejlesztési hibákról, visszahívott termékekről is hallhatunk. Ennek okai többrétűek lehetnek, mint a technológia életképtelensége, túlhaladottsága, a termék rossz piaci fogadtatása. Ha ezektől a tényezőktől eltekintünk, akkor a legtöbb sikertelen vagy bedőlt projekt oka a körültekintő tervezés, a hatékony változtatás és kockázatkezelés hiánya miatt fellépő határidő- vagy költségkeret túllépés. A különböző tevékenységekhez füződő hibákból adódóan a részprojektekben be nem tartott mérföldkövek következményeként a teljes projekt egészére kiható határidőcsúszás az eredmény. Bizonyos mértékű csúszást a tervezett pufferek kompenzálnak, de halmozódáskor láncreakció indul el.

A jelen tanulmány nem az erőforrásbecslés hiányából vagy a helytelen tervezésből adódó időveszteségek miatt bekövetkező kiváltó okokat elemzi. Az ilyen nyilvánvaló okok, veszélyek feltárása és kezelése a projekt portfólió menedzsment testület hatáskörébe esik, mely általában létezik, és jól működik a nagyobb projektszervezetekben. A szakirodalomban fellelhetó általános kutatások eredményein túlmutatóan azt vizsgáljuk, hogy azonosítható-e az aktuális járműipari szervezeti projektmun- 


\section{TEMATIKUS TANULMÁNYOK - Menedzsment: vezetők, vezetés és munkavállalók}

kában önálló jellegzetesség. Az egyének belső motivációja, hozzáállása a teljesítendő projektfeladatok minőségét és a teljes projekt eredményességét befolyásolja. A projekt - definíciója szerint - egyszeri feladat megoldására jön létre, időnyomásos helyzetet teremthet, ami az egyéni, csoportos és szervezeti együttmúködésre nézve sajátos körülményeket hoz létre. Az egyén saját preferenciái, készségei, meggyőződése mentén hoz döntéseket és veszi ki részét az együttműködésből. A járműipar a legnagyobb innovátorok közé tartozik, ezért a változtatások a szektorra vetítve sajátosak, gyakoriak és jelentős mértékűek. A tanulmány a járműipari projekttagok határidőhöz füződő viszonya, projektekben gyűjtött tapasztalata és motivációja tükrében elemzi és ábrázolja a projekt teamek összetételét. A vizsgálatnak nem célja a motivátor vagy demotivátor kiváltó okának felderítése.

\section{Irodalmi áttekintés}

Chikán (2008) szerint a versenyképesség függ az innovációtól. Az időben realizált innováció technológiaközpontú világunkban jelentős versenyelőnyhöz juttathatja a vállalatokat.

Termékfejlesztés alatt az új ötletek keresésétől a termék piaci bevezetéséig tartó tevékenységek összességét értjük (1. ábra). Az életciklus - a vízszintes tengelyen került ábrázolásra - és a termék teljes élettartamát ábrázolja az ötlet alapján megindított fejlesztéstől a termelésből kivonásig. A függőleges tengelyen az ipari szereplő bevételének és kiadásának mértékét jelöljük. A termék piacra kerüléséig, az első (1) és második (2) fázis időtartama alatt nem vagy csak kis mértékben termel bevételt, tehát negatív hatású a szervezet vagyonára. A termék-tervezés korai fázisában akkor

\section{1. ábra. A termékfejlesztés folyamata}

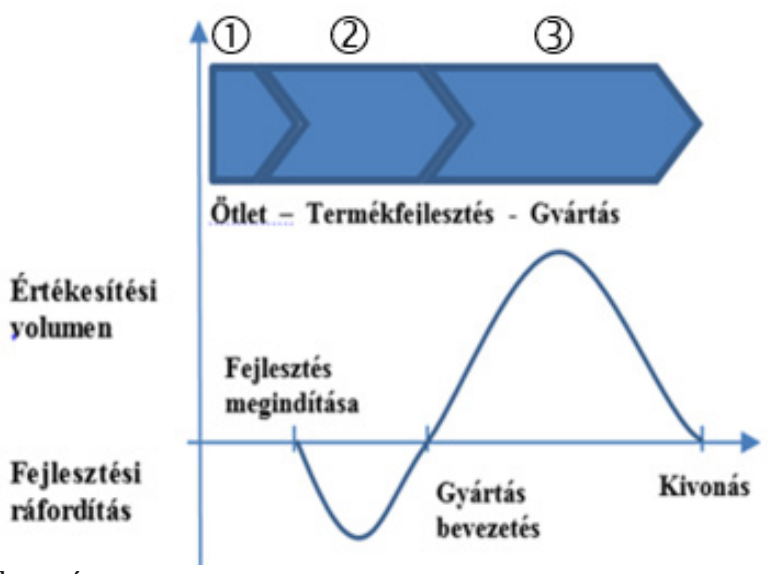

Forrás: Saját szerkesztés. 


\section{TEMATIKUS TANULMÁNYOK - Menedzsment: vezetők, vezetés és munkavállalók}

termelődik bevétel, ha résztermék vagy technológia piacosítása mellett dönt vagy fejlesztési konzorciumban együttműködő partnere hamarabb piacra viszi a közösen fejlesztett egységet, és ezzel licencdíj áramlik. Optimális esetben, a harmadik (3) fázisban a szervezet ráfordításait meghaladja a bevétel, és nyereség keletkezik, ami pozitív hatású. Az időtényező kiemelt szerepet játszik a fejlesztésekben. Az életgörbe a már kidolgozott, termelésbe bevezetett termék értékesítési volumen-változását írja le. Szendi és Székely (2015) kutatása szerint a termékek életciklusa lerövidült, az új gépjárműmodellek fejlesztése már nem hét, hanem három-négy évet vesz igénybe, ami a fejlesztőket is nagyobb kihívások elé állítja (2. ábra). Az 1. ábra felhasználásával az AUDI TT példáján szemléltetjük a modellpaletta fejlesztésének következményeit. Az ábrában a termékéletciklus-diagramok eloszlása látható az idő függvényében. Megfigyelhető, hogy 2008 előtt két típus létezett. Az ezt követő időszakban ugyanarra a platformra négy típus lett felépítve. Emellett az ábra jobb felső négyzetében az került ábrázolásra, hogy egy újabb gyáregység épült a típusvariancia és a növekvő darabszám lefedésére.

\section{2. ábra. Termékfejlesztési és szervezetfejlesztési ciklusok}

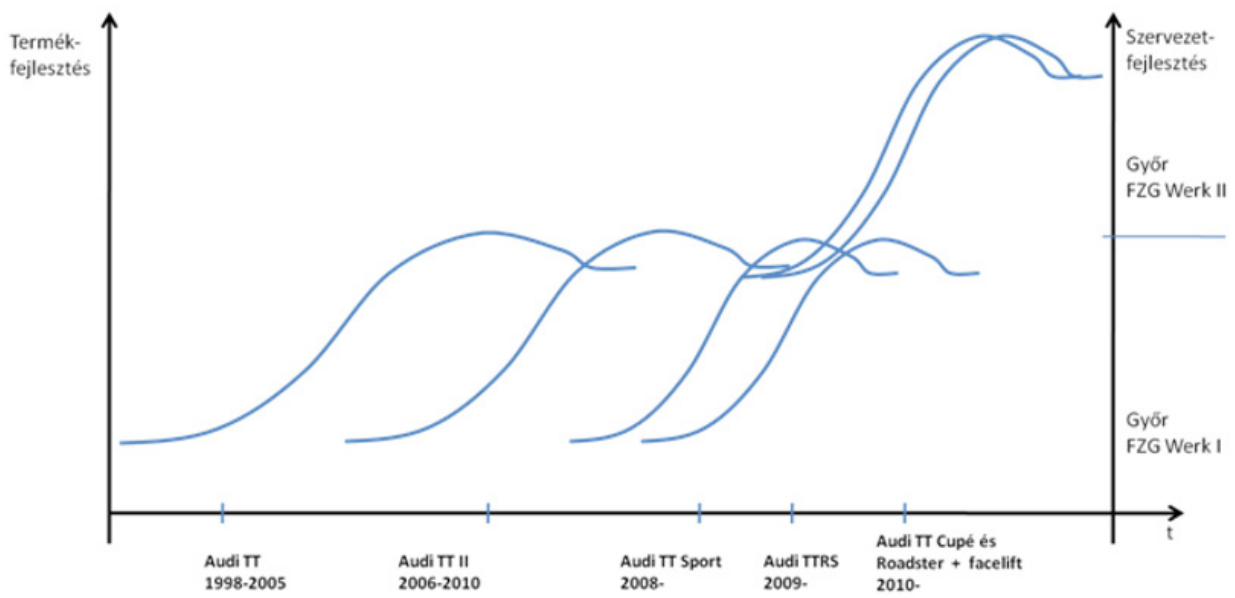

Forrás: Saját szerkesztés

Schumpeter (2001, eredeti 1939) elgondolásából kiindulva, járműipari fejlesztések esetén minden növekedési szakasz és érettség után a karosszéria, motor továbbfejlesztése vagy új modell kifejlesztése szükséges. A termékfejlesztés projektek formájában valósul meg, amelyben az emberi erőforrás - a többi erőforrással öszszevetve - kiemelt szerepet kap. Az idevágó nemzetközi és magyar szakirodalom 


\section{TEMATIKUS TANULMÁNYOK - Menedzsment: vezetók, vezetés és munkavállalók}

(Bakacsi 2015 :12) is hangsúlyozza, hogy legjobb termékötlet, stratégia és terv sem valósítható meg jól együttmúködő, lelkes emberek munkája nélkül. Az emberi tényező napjainkban sokak szerint annyira fontos, hogy tőkeelemként kezelendő. Különösen igaz ez a megállapítás azokra a tevékenységekre, melyek tudásszükséglete magas, nehezen pótolható, stratégiai fontosságú. Az ilyen tudással bíró szakemberek és vezetők elvándorlása a vállalattól kimutatható, esetenként meghatározó mértékű pénzügyi veszteségként realizálódik.

A termékfejlesztés a különböző szervezeti egységekkel együtt teammunkában, autóiparban egyidejű mérnöki munkában (simultaneaus engineering) valósul meg, azonban az eredményesség és a hatékonyság az emberi erőforrás magatartásától függ. A vezetők az eredményeket csak mások munkája révén érhetik el, azaz a projektcsapat összetétele a projekt hatékonyságát befolyásolja. Minden projekt az idő, költségek és a minőség (projektháromszög) között egyensúlyoz. Az idő versenyelőnyt növelő tényező (termékek időben történő leszállítása, a versenytársak fejlesztéseit megelőzve új termék fejlesztése). Innovátorok szerepe kiemelkedő a termékfejlesztésben (Miller - Roth 1994).

Az időtényező a projektmunkában magában foglalja a meghatározott feladatok és részfeladatok határidőre történő elkészítését, az egyeztetések eredményes lebonyolítását, a projekthatáridők (mérföldkövek, kezdő és befejező határidők) betartását és az eredmények leszállítását. Ezek a tényezők megmutatják a mutató elhelyezkedését a vevőközpontúság és az öncélú projekttevékenység végpontok között. A fenti paraméterek sérülése esetén a projekt eredményes lezárása veszélybe kerülhet, a tervezett határidő túllépése a költségek változását vonja maga után, kulcsérdekeltek kihátrálhatnak a projektből, támogatásvesztés, projektrizikó halmozódás, szerződésszegés esetén szankciók (kötbér) kivetését és végül a fogyasztók, ügyfelek elvesztését vonhatja maga után. Más szemszögből vizsgálva a veszélyeket csoportosíthatunk a külső környezeti hatások, a jogszabályok, uniós környezetvédelmi és jármű biztonsági előírások és a belső hatások: a projektcsapat összetételét megváltoztató személyi változások (kulcsember kilépése), a hiányzó szaktudás pótlása többletköltséget, időveszteséget is jelent a projekt számára és a tervezésből adódó hibák (kapacitásbecslés, időtartambecslés) szerint is. A szervezeti magatartás három illeszkedési szintje (egyén, csoport és szervezet) közül az egyén és csoport illeszkedési szintjére összpontosítva megállapítható, hogy az egyének személyes céljai, a szervezettel szemben tanúsított elvárásai és a szervezet projektszintre lebontott céljainak összhangba hozása a vezetés „meghatározóan fontos” feladata. „A szervezet csak egyéni hozzájárulások, teljesítmények révén érheti el célját” (Bakacsi 2015: 18). Egyrészt, hogy az egyént mi motiválja a szervezeti célok elérésére, beáll-e a szervezeti célok mögé, másrészről a szervezeten belül múködő projektcsapat, hogy képes az egyén céljait támogatni. A motiváció elméletekkel több kutató is foglalkozott (1. táblázat). 
www. metszetek.unideb.hu

\section{TEMATIKUS TANULMÁNYOK - Menedzsment: vezetők, vezetés és munkavállalók}

1. táblázat. A motiváció tartalomelméleteinek összevetése

\begin{tabular}{|c|c|c|c|c|c|c|}
\hline & $\begin{array}{c}\text { Maslow } \\
\text { szükséglet } \\
\text { hierarchia }\end{array}$ & & $\begin{array}{c}\text { Herzberg két-tényező } \\
\text { elmélete }\end{array}$ & Alderfer & McClelland & Hunt \\
\hline \multirow{2}{*}{$\begin{array}{l}\text { magasabb } \\
\text { rendú } \\
\text { szükséglet }\end{array}$} & önmegvalósítás & \multirow{2}{*}{$\begin{array}{l}\text { (F) } \\
\text { motivá- } \\
\text { torok } \\
\text { (belső) }\end{array}$} & \multirow{2}{*}{$\begin{array}{c}\text { a munka tartalma, } \\
\text { felelősség előmenetel, } \\
\text { fejlődés }\end{array}$} & \multirow{2}{*}{ fejlődés } & \multirow{2}{*}{$\begin{array}{l}\text { teljesítmény } \\
\text { szükséglet }\end{array}$} & önmegvalósítás \\
\hline & elismerés & & & & & hatalom \\
\hline & \multirow[b]{2}{*}{$\begin{array}{l}\text { szeretet (valahová } \\
\text { tartozás, társas } \\
\text { kapcsolat) }\end{array}$} & \multirow{4}{*}{$\begin{array}{l}\text { higié- } \\
\text { niás } \\
\text { ténye- } \\
\text { zők ( . } \\
\text { külső) }\end{array}$} & teljesítmény, elismerés & \multirow[b]{2}{*}{ kapcsolat } & \multirow[b]{2}{*}{$\begin{array}{l}\text { hatalmi } \\
\text { szükséglet }\end{array}$} & elismertség \\
\hline \multirow{3}{*}{$\begin{array}{l}\text { alacsonyabb } \\
\text { rendü } \\
\text { szükséglet }\end{array}$} & & & $\begin{array}{c}\text { személyközi } \\
\text { kapcsolatok minősége } \\
\text { munkatársakkal, } \\
\text { beosztottakkal Is } \\
\text { főnökökkel }\end{array}$ & & & kapcsolat \\
\hline & biztonság & & munka biztonsága & \multirow{2}{*}{ létezés } & \multirow{2}{*}{$\begin{array}{l}\text { kapcsolat } \\
\text { szükséglet }\end{array}$} & struktúráltság \\
\hline & fiziológia & & munkafeltételek, fizetés & & & komfort \\
\hline
\end{tabular}

Forrás: Bakacsi (2015: 88)

Maslow (1950) a motivációt kutatva a szükségleteket öt hierarchia szintre bontva ábrázolja amely a létfenntartáshoz nélkülözhetetlen alapszükségleteket, a biztonsági szükségleteket, szociális szükségleteket, elismerés iránti szükségleteket és az önmegvalósítás szükségletét tartalmazza. Az 1. táblázat első oszlopában a szükségletek bontása látható, ahol az A és B pontok közötti tartományban az alacsonyabb rendű, a B és $C$ pontok között pedig magasabb rendű szükségletek állnak szerzőnként összeállítva. Az új szükségletek akkor lépnek fel, ha az alacsonyabb szinten lévő szükségleteket már kielégítették. Motiváló erővel mindig a magasabb szinten lévő szükséglet bír, a kielégített szükséglet már nem motivál. Átvezetve ezt a gondolatot a szervezeti tevékenyégre könnyen belátható, hogy az alapszükségleteiért versengő individuum kevésbé hatékony módon tud azonosulni a szervet céljaival. A motiváció ilyen, alacsonyrendű szükségletekkel táplálása kevésbé jellemző a modern szervezetekre.

Herzberg (1960) motiváció tartalomelméleti modellje két tényezőt emel ki, a munkahelyi elégedettség okozóit (higiénés tényezőket), mint a vállalati politika, vezetés, kapcsolat a felettesekkel, fizetés, kapcsolat a munkatársakkal, munkafeltételek és az elégedettséghez vezető tényezőket (motivátorok), melyeket a teljesítmény, elismertség, maga a munka, felelősség, előrejutás, növekedés csoportokba sorol. Az 1. táblázat harmadik oszlopától jobbra - szerzőnként - a motivátorok csoportosítása került a táblázatba, ahol a D és E pontok közötti tartományban külső, az E és F pontok között pedig a belső motivátorok láthatóak.

McClelland (1985) elmélete szerint a motivációk tanultak, a társadalmi fejlődés különböző szakaszaiban eltérőek. A kapcsolat-, teljesítmény-, hatalomelmélet három szükségletet különböztet meg, amelyekkel a motivációk szervezeti környezet- 


\section{TEMATIKUS TANULMÁNYOK - Menedzsment: vezetók, vezetés és munkavállalók}

ben magyarázhatók, ezek pedig a kapcsolati motiváció (együttmúködés, társas kapcsolatok kialakítása), a teljesítmény motiváció (kitűzött célok elérése), és a hatalmi motiváció (vágy mások kontrolálására).

Más szerzők (Bakacsi 2015, Berde 2014, Dobák 2014, Papp 2016) is megjegyzik hogy az alapszükségleteken túl a munkahelyeken is létezik egy árnyaltabb motivációs struktúra, ahol fontos tényező a tanulás, tudásszerzés és motiváció. Szervezetfejlesztési szempontból fontos feladat feltérképezni és támogatni a szervezeti tagok egyéni motivációs faktorait. Példaként megemlíthető a nem anyagi motivációs tényezők közül a továbbképzési lehetőség, fontos feladat, új témakör megismerése és különleges feladatok elsajátításának, a munkahelyi specializációnak az elősegítése. Ezek a tényezők nagyobb gyakorisággal fordulnak elő a tanulmány fókuszában álló projektekben, mint a rutinfeladatok területén.

Hunt (1965) a munkahelyi motivációt az egyéni célok irányából és nem az egyéni szükségletek felől közelíti meg. A cél-motiváció elmélet alapján az egyén magatartását a célok irányítják, amelyek munkatapasztalattól és életszakasztól, életkortól függően változnak.

Rappaport (1981) alapján az empowerment az egyének önmegvalósításának részévé teszi a szervezet céljait azáltal, hogy teret enged az egyéni döntéseknek a vezetőség által kijelölt mozgástartományon belül. Az önmegvalósítás kiemelkedő egyéni teljesítményre ösztönöz. Az önmegvalósító egyének belső motivációja az átlagos egyénhez viszonyítva magasabb. Azonban az önmegvalósító egyének magas aránya, többsége a projektcsapatban nem mindig vezet eredményre, illetve nem minden személyiségtípus tud mit kezdeni a „szabadsággal”. Csapatjáték szempontjából a túl önálló, nehezen irányítható egyének túlsúlya negatívan befolyásolja a projektkultúrát.

Az idő szerepét a gyártási folyamatokban a történelem során más-más szemszögből érzékelték. Taylor és Gantt óta azonban ez is egy az erőforrások közül. Ennek megfelelően van értéke, nyeresége és vesztesége. Bába és Berde (2010) aktuális kutatási eredményei alapján a vezetők több időt töltenek kommunikációval és információszerzéssel, mint tervezéssel és döntéssel. A szervezet méretének növekedésével nőtt az ezekre fordított idő is. Ha ezt az eredményt párhuzamba állítjuk a projektek méretével, hasonló összefüggés lenne kimutatható.

\section{Kutatás}

A kutatás célja áttekintést nyerni arról, hogyan viszonyulnak a projekt tagjai a határidőkhöz, mennyire motiváltak, hogyan viselkednek a projektben. A tanulmány elkészítését korábbi munkahelyi tapasztalataim és személyes élményeim is ösztönözték, mert régóta foglalkoztat a gondolat - az erőforrások hiányát leszámítva - mi lehet még annak az oka, hogy nem sikerül betartani és betartatni a kitűzött határidőket. 


\section{TEMATIKUS TANULMÁNYOK - Menedzsment: vezetők, vezetés és munkavállalók}

A célcsoportot autóipari multinacionális nagyvállalatok és kis- és középvállalkozások, beszállítók alkalmazottai alkották, akik projektekben belső vagy külső érintettként szerepeltek. Projektben betöltött szerepük alapján projektvezetőként, projekttagként, projekt-adminisztrátorként vagy külső érintettként olyan feladatokat látnak el, amelyek egy meghatározott cél eléréséhez járulnak hozzá, adott minőségi és szállítási feltételeket, a kitűzött határidőket és rendelkezésre álló források hatékony felhasználását szem előtt tartva. A megkérdezettek autóipari beszállítóként konstrukcióval, minőségüggyel foglalkozó mérnökirodák alkalmazottai Pozsonyban, Ingolstadtban, Győrben vagy Kecskeméten.

A felmérés során kihívást jelentett azon hiteles személyek felkutatása, akik releváns járműipari munkatapasztalattal rendelkeznek, és nem kizárólag napi rutinfeladatokat látnak el, hanem részt vettek már termékfejlesztési projektekben is. Ezen feltételek teljesülése jelentősen leszűkítette a megkérdezés célcsoportját, korlátozta azon személyek számát, akik a tervezett mintának megfeleltek, ez alapján a megkérdezettek száma 64 főre szűkült és alacsony elemszámot eredményezett.

A primer kutatás kvantitatív vizsgálati módszereket alkalmazva, standardizált kérdőíves módszerrel készült. A felmérés módja önkitöltős kérdőíves megkérdezés, amely papír alapon történt. A kérdőívek feldolgozásához SPSS 20.0 szoftvert használtam, egy és többváltozós statisztikai elemzéseket készítettem.

A statisztikai elemzések közül a klaszterezést használtam, több változó szerint csoportosítva a megfigyelési egységek számának csökkentését végeztem. A hasonló elemek valamilyen szempont szerint egy klaszterbe, a nem hasonló elemek más-más klaszterbe kerülnek. Célszerű volt a hierarchikus összevonó eljárás választása a kis elemszám és az ismeretlen mennyiségű várható klaszterek száma miatt. Az elemzés célja, hogy a klaszterben lévő elemek közti távolság minimális, de a klaszterek közötti távolság lehetőleg maximális legyen. Hátránya, hogy a klaszteranalízis akkor is létrehoz csoportokat, ha az adatok között nincs kapcsolat. Klaszteranalízis típusai közül a hierarchikus eljárást választottam, amely az egymáshoz legközelebb eső elemeket vagy klasztereket vonja össze, amelyek az utolsó lépésig együtt maradnak.

A rendelkezésre álló minta 64 elemből áll, ami a mintaelemek távolság mátrixának problémamentes tárolását teszi lehetővé. A változók a motiváció, határidőtartás és tapasztalat voltak.

Motiváció: a változó jellemzi, hogy a projekttagok milyen mértékben találják feladataikat lelkesítőnek, és tölti el őket a feladatelvégzés végeztével elégedettség. A mérésnél motivációt jellemző tényezőket értékeltek a megkérdezettek. A hajtóerők átlaga adta meg az összmotiváció mértékét.

Határidőtartás: A határidőtartás változónál a megkérdezettek a projekt szempontjából értékelték, hogy mennyire tartják fontosnak a határidő betartását vagy inkább a legjobb termék létrehozása, eredmény elérése jelenti számukra a magas prioritású, kedvelt feladatot. 


\section{TEMATIKUS TANULMÁNYOK - Menedzsment: vezetők, vezetés és munkavállalók}

Tapasztalat: A tapasztalat mérése egyszerű adatlekérdezés, ahol a válaszadók a megadott értéktartományok közé sorolták be saját projektben eltöltött munkaidejük hosszát. Ez a teljes munkatapasztalattól rövidebb lehet, nem mindenki tölti a teljes szakmai karrierjét projektekben.

A nem reprezentatív minta demográfiai összetétele alapján általános eloszlást mutatott. A 18-25 éves korosztály (4,7\%), a 26-35 éves korosztály $(18,8 \%)$, a 36-45 éves korosztály (54\%) a 46-55 éves korosztály pedig (21\%) arányban vett részt a felmérésben. A nemek szerinti megoszlás a 2. táblázatban látható. Megfigyelhető, hogy a nők aránya 22\% (14 fő) jóval kisebb, mint az ebben a szegmensben tevékenykedő férfiak aránya 78 \% (50 fő). A korcsoport szerinti megoszlás a nőknél nagyobb arányú fiatal kezdőt mutat, majd ez a tendencia a korral arányosan csökken. A férfiak csoportjában nő a korcsoporton belüli arány. Közel ugyanannyi nő és férfi választja a korcsoporton belül a feladatkört, kezdetben arányosan több nő, mint férfi.

2. táblázat. Kereszttábla elemzés: a megkérdezettek neme és életkora

\begin{tabular}{|l|l|c|c|c|c|}
\hline \multicolumn{2}{|c|}{} & \multicolumn{3}{|c|}{ Megkérdezettek életkor szerinti megoszlása } \\
\cline { 2 - 6 } \multicolumn{2}{|c|}{} & $18-25$ év & $26-35$ év & $36-45$ év & $46-55$ év \\
\hline \multirow{3}{*}{$\begin{array}{l}\text { Megkérdezettek nemek } \\
\text { szerinti megoszlása }\end{array}$} & Nő [14 fö] & 1 & 3 & 8 & 2 \\
\cline { 2 - 6 } & & $7,1 \%$ & $21,4 \%$ & $57,1 \%$ & $14,3 \%$ \\
\hline \multirow{2}{*}{ Osszesen } & Férfi [50 fö] & $4,0 \%$ & $18,0 \%$ & $54,0 \%$ & $24,0 \%$ \\
\hline & & 3 & 12 & 35 & 14 \\
& 64 fö & $4,7 \%$ & $18,8 \%$ & $54,7 \%$ & $21,9 \%$ \\
\hline
\end{tabular}

Forrás: Saját szerkesztés

A 3. táblázat megerősíti az előbbi megfigyelést a nemek arányával kapcsolatban, azonban az is látszik, hogy a nemek csoportján belül arányosan ugyanannyi tapasztalt női alkalmazott van a pályán, mint projektes munkakört gyakorló férfi. Viszont az is látható, hogy 36-45 éves korosztályban a nemenkénti életkor aránya majdnem egyenlő, a 46-55 éves korosztály képviselői még kevesebben választották ezt a munkakört. A fiatalabb korosztályban a csoportra vetítve több nő vállal projektben feladatot. 
www. metszetek.unideb.hu

\section{TEMATIKUS TANULMÁNYOK - Menedzsment: vezetők, vezetés és munkavállalók}

3. táblázat. Kereszttábla elemzés: a megkérdezettek neme és projekttapasztalata

\begin{tabular}{|c|c|c|c|c|c|}
\hline & \multicolumn{3}{|c|}{ Megkérdezettek tapasztalata } & \multirow[b]{2}{*}{$\begin{array}{c}\text { több, } \\
\text { mint } 10 \text { év }\end{array}$} \\
\hline & & $\begin{array}{l}\text { kevesebb, } \\
\text { mint } 3 \text { év }\end{array}$ & 3-5 év & 6-10 év & \\
\hline \multirow{2}{*}{$\begin{array}{l}\text { Megkérdezettek nemek } \\
\text { szerinti megoszlása }\end{array}$} & Nő [14 fö] & $\begin{array}{c}3 \\
21,4 \% \\
\end{array}$ & $\begin{array}{c}5 \\
20,0 \% \\
\end{array}$ & $\begin{array}{c}4 \\
28,6 \% \\
\end{array}$ & $\begin{array}{c}2 \\
14,3 \%\end{array}$ \\
\hline & Férfi [50 fő] & $\begin{array}{c}6 \\
12,0 \% \\
\end{array}$ & $\begin{array}{c}10 \\
20,0 \% \\
\end{array}$ & $\begin{array}{c}22 \\
44,0 \% \\
\end{array}$ & $\begin{array}{c}12 \\
24,0 \% \\
\end{array}$ \\
\hline Osszesen & 64 fö & $\begin{array}{c}9 \\
14,1 \%\end{array}$ & $\begin{array}{c}15 \\
23,4 \%\end{array}$ & $\begin{array}{c}26 \\
40,6 \% \\
\end{array}$ & $\begin{array}{c}14 \\
21,9 \%\end{array}$ \\
\hline
\end{tabular}

Forrás: Saját szerkesztés

A megkérdezettek nemek szerinti megoszlása után tekintsük meg a szerepek szerinti adatok alakulását. A kutatásban résztvevő 64 fő közül 3 fő megbízóként, 6 fő külső érintettként, 13 fő projektvezetőként, 40 fő projekttagként, 1 fő projektaszszisztensként, 1 fő projekttanácsadóként vett részt járműipari projektekben.

Az adatokból szembetűnik, hogy a résztvevők 62,5\%-a projekttagként tevékenykedik, a projektasszisztensek (1,6 \%) a dokumentációt és a szervezési feladatokat végzik, párhuzamosan egyszerre akár több projektben is dolgozhatnak. Külső érintettek $(9,4 \%)$ alatt azokat a személyeket értjük, akik nem részesei a projektnek, de mégis kapcsolatban vannak vele. Például a kontrolling osztály munkatársai nem projekttagok egy karbantartási projektben, de adat ellenőrzéssel már érintetté válnak, azonban egy kontrolling projektben már projekttagként szerepelnek.

Grafikusan ábrázolva azok a különbséget okozó kiugró (outliers) és extrém adatok is láthatók, amelyek a vizsgálat eredményeit torzíthatják. Az x változókat (határidők tartása, motiváció) külön-külön pontdiagrammal ábrázolva látható a csoportok képződése és a kiugró értékek.

A projektben résztvevők gyakorlati szaktudását, autóiparban eltöltött tapasztalatát és projekt határidejének betartását 5 fokozatú Likert-skálán ábrázolva vizsgáltam. A feldolgozott adatok eloszlása a skála 3-5 fokozata körül helyezkedik el, kiugró adatként egy adat (47) szerepelt (3. ábra). A válaszadók többsége inkább pozitívabban nyilatkozik a határidőtartás és a tapasztalat változók esetében. Az optimizmus az iparágra jellemző változékonyság, feladatmennyiség és határidőnyomás ellenére adottnak látszik. 
www. metszetek.unideb.hu

\section{TEMATIKUS TANULMÁNYOK - Menedzsment: vezetők, vezetés és munkavállalók}

3. ábra. Projekttagok tapasztalata és a határidő betartása

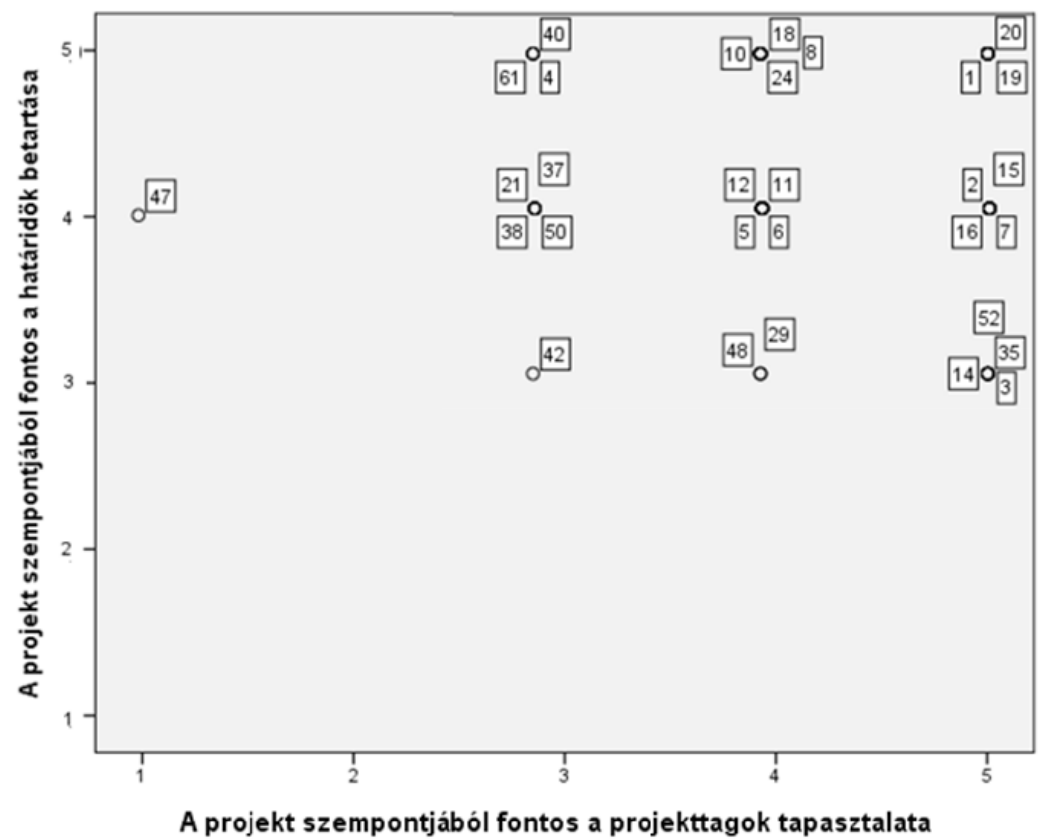

Forrás: Saját szerkesztés

A feldolgozott válaszok többsége ebben az esetben is a Likert-skála 3-5 fokozatán helyezkedik el, kiugró adatként két adat (4) és (47) szerepelt. (4. ábra). Hasonló képet mutat a határidők betartása és a motiváció kapcsolata is, inkább többségben van a pozitív válaszadó. 
www. metszetek.unideb.hu

\section{TEMATIKUS TANULMÁNYOK - Menedzsment: vezetők, vezetés és munkavállalók}

4. ábra. Motiváció és a határidők betartása

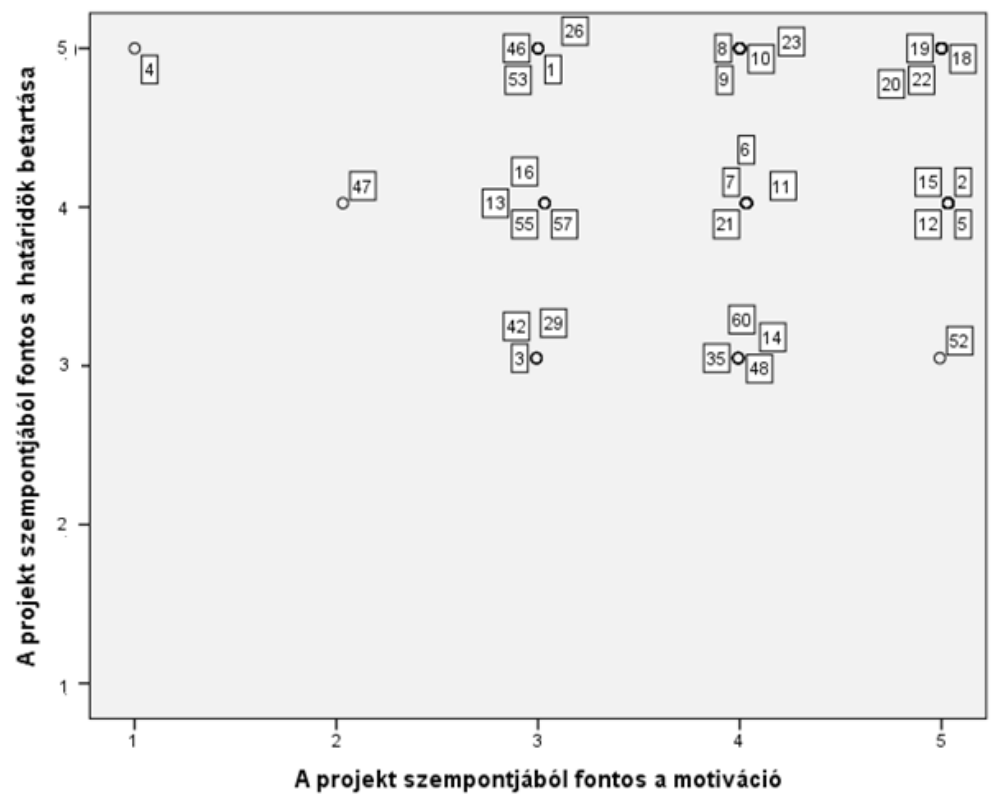

Forrás: Saját szerkesztés

A 4. táblázat az átlagokat és a szórásokat tartalmazza. A válaszadók véleménye szerint a három tulajdonság egyaránt fontos, a határidők betartását látják $(4,31)$ a legfontosabbnak. A motiváció megítélésével kapcsolatban a legnagyobb a szórás, ezzel a válaszok sokszínűsége.

4. táblázat. Átlagok és szórások

\begin{tabular}{|l|c|c|c|}
\hline & Átlag & Szórás & $\begin{array}{c}\text { Elemszám } \\
{[\mathrm{db}]}\end{array}$ \\
\hline A projekt szempontjából fontos a határidők betartása & 4,31 & 0,687 & 64 \\
A projekt szempontjából fontos a motiváció & 4,16 & 0,877 & 64 \\
A projekt szempontjából fontos a projekttagok tapasztalata & 4,2 & 0,8 & 64 \\
\hline
\end{tabular}

Forrás: Saját szerkesztés 


\section{TEMATIKUS TANULMÁNYOK - Menedzsment: vezetők, vezetés és munkavállalók}

A kapott eredményeket egymáshoz viszonyítva relatív homogén adateloszlást látunk. Ez utalhat a minta alacsony elemszámából adódó csoportosulásra, vagy természetes klaszterképződésre is. A továbbiakban a statisztikai eljárások közül a dimenziócsökkentő klasztereljárással a megfigyelési egységeket homogén csoportokba soroltam, klasszifikáltam (Sajtos-Mitev 2007). A változók közötti kapcsolat szorosságát és irányát a Pearson- féle korrelációs együtthatóval vizsgáltam (5. táblázat). A statisztikai vizsgálat elvégzése után a kapott korrelációs együtthatók $(0,128$, 0,339, 0,027) alapján látható, hogy nem korrelálnak egymássál, ezért elvégezhető a klaszteranalízis. A Ward- féle eljárás, azokat a csoportokat vonja össze, amelyek a klaszteren belül szórásnégyzetet a legkevésbé növelik. Előnye, hogy kevésbé érzékeny a kiugró adatokra.

5. táblázat. Pearson-féle korreláció

\begin{tabular}{|c|c|c|c|c|}
\hline & & $\begin{array}{c}\text { A projekt szempontjából } \\
\text { fontos határidők } \\
\text { betartása }\end{array}$ & $\begin{array}{c}\text { A projekt szempontjából } \\
\text { fontos motiváció }\end{array}$ & $\begin{array}{c}\text { A projekt szempontjából } \\
\text { fontos a projekttagok } \\
\text { tapasztalata }\end{array}$ \\
\hline \multirow{2}{*}{$\begin{array}{l}\text { A projekt } \\
\text { szempontjából fontos } \\
\text { határidők betartása }\end{array}$} & $\begin{array}{l}\text { Person féle korrelációs } \\
\text { együttható }\end{array}$ & 1 & 0,128 & 0,027 \\
\hline & \begin{tabular}{|l|} 
A korreláció szignifikancia \\
szintje
\end{tabular} & & 0,312 & 0,832 \\
\hline \multirow{2}{*}{$\begin{array}{l}\text { A projekt } \\
\text { szempontjából fontos } \\
\text { motiváció }\end{array}$} & $\begin{array}{l}\text { Person féle korrelációs } \\
\text { együttható }\end{array}$ & 0,128 & 1 & 0,339 \\
\hline & \begin{tabular}{|l|}
$\begin{array}{l}\text { A korreláció szignifikancia } \\
\text { szintje }\end{array}$ \\
\end{tabular} & 0,312 & & 0,006 \\
\hline \multirow{2}{*}{$\begin{array}{l}\text { A projekt } \\
\text { szempontjából fontos } \\
\text { a projekttagok } \\
\text { tapasztalata }\end{array}$} & $\begin{array}{l}\text { Person féle korrelációs } \\
\text { együttható }\end{array}$ & 0,027 & 0,339 & 1 \\
\hline & \begin{tabular}{|l|} 
A korreláció szignifikancia \\
szintje
\end{tabular} & 0,832 & 0,006 & \\
\hline
\end{tabular}

Forrás: Saját szerkesztés

A klaszterelemzésbe közvetlenül a projekt hatékonyságához hozzájáruló - az autóipari projektmenedzsment eredményességét is meghatározó - három releváns változót vontam be.

A függő változó a „a projekt szempontjából fontos a határidők betartása”, „a projekt szempontjából fontos a motiváció”-tól és a „projekt szempontjából fontos a projekttagok tapasztalatá"-tól függ. Az esetek összegzése alapján látható, hogy nincs hiányzó adat.

A klaszterek esetében grafikusan dendogrammal ábrázolva, a megfelelő helyen elvágva bármilyen klaszterszám előállítható a megrendelők igényeinek megfelelően. Az első klaszterelemzésnél 4 klasztert kaptam, míg a második kiugró értékek $(4,47)$ nélkül elvégzett klaszterelemezés után, az esetszám 62-re redukálódott és így 3 klaszter maradt. 


\section{TEMATIKUS TANULMÁNYOK - Menedzsment: vezetők, vezetés és munkavállalók}

A mintát vizsgálva megállapítható, hogy az első klaszterbe 21, a másodikba 34 és a harmadikba 7 elem tartozik (6. táblázat).

Határidők betartását vizsgálva az első klaszterben az átlag értéke $(4,24)$ a teljes átlag $(4,31)$ értékéhez viszonyítva alacsonyabb, de több mint a harmadik klaszterben. Ebben a csoportban vannak azok a projektrésztvevők, akik számára a határidők betartása kevésbé fontos, mint az átlag számára.

Motiváció szempontjából a csoport átlagértéke $(3,71)$ kisebb, mint a teljes átlag $(4,24)$ értéke. A klaszter tagjai nem annyira motiváltak, mint a többiek és a kisebb mértékben képesek lelkesen, odaadással hozzátenni a projekt sikeréhez. A motivációt elemezve látható, hogy a legnagyobb értéket a második klaszterbe került csoport mutatja. Az átlagostól nagyobb értéket ebben az egy klaszterben figyeltem meg.

A projekttagok tapasztalata szempontjából vizsgálva az első klaszterben csoportátlag $(3,71)$ kisebb, mint teljes átlag $(4,27)$. A csoport tagjai arányosan kevesebb projektmenedzsment tapasztalattal rendelkeznek, mint a csoportra jellemző átlagos tapasztalat mértéke.

6. táblázat. Klasztercentroidok és átlagok három klaszter esetén

\begin{tabular}{|c|c|c|c|c|}
\hline Csoportátlagok & 1. klaszter & 2. klaszter & 3.klaszter & Összesen \\
\hline Tagság fố / \% & $\begin{array}{c}21 \\
34 \%\end{array}$ & $\begin{array}{c}34 \\
55 \%\end{array}$ & $\begin{array}{c}7 \\
11 \%\end{array}$ & $\begin{array}{c}62 \\
100 \%\end{array}$ \\
\hline \multicolumn{5}{|l|}{ Változók } \\
\hline $\begin{array}{l}\text { határidốk } \\
\text { betartása }\end{array}$ & 4,24 & 4,62 & 3,00 & 4,31 \\
\hline $\begin{array}{l}\text { motiváció } \\
\text { fontossága }\end{array}$ & 3,71 & 4,65 & 3,86 & 4,24 \\
\hline $\begin{array}{l}\text { a tapasztalat } \\
\text { fontossága }\end{array}$ & 3,71 & 4,53 & 4,71 & 4,27 \\
\hline \multicolumn{5}{|l|}{ Egyéb változók } \\
\hline életkor & $\begin{array}{l}18-25 \text { év } \\
26-35 \text { év }\end{array}$ & 26-35 év & $\begin{array}{l}\text { inkább } \\
\text { 26-35 év }\end{array}$ & - \\
\hline neme (férfi/nô) & $\begin{array}{c}\text { többségében } \\
\text { nố }\end{array}$ & $\begin{array}{l}\text { hasonló } \\
\text { arányban }\end{array}$ & $\begin{array}{c}\text { inkább } \\
\text { férfi }\end{array}$ & - \\
\hline \begin{tabular}{|l} 
projekttapasztalat \\
hossza
\end{tabular} & inkább 3-5 év & változó & $\begin{array}{l}\text { inkább több, } \\
\text { mint } 10 \text { év }\end{array}$ & - \\
\hline betöltött szerep & $\begin{array}{c}\text { Projekttag, } \\
\text { projektaszitnes }\end{array}$ & $\begin{array}{c}\text { Projektvezetô, } \\
\text { megbízó }\end{array}$ & projekttag & - \\
\hline Klaszterek elnevezése & $\begin{array}{l}\text { pontos, megbízható } \\
\text { feladatvégrehajtók }\end{array}$ & $\begin{array}{c}\text { kiváló, tapasztalat } \\
\text { alkalmazott }\end{array}$ & $\begin{array}{l}\text { nagy tapasztalatú, } \\
\text { de túltervezére } \\
\text { hajlamos szakértôn }\end{array}$ & - \\
\hline
\end{tabular}

Forrás: Saját szerkesztés 


\section{TEMATIKUS TANULMÁNYOK - Menedzsment: vezetők, vezetés és munkavállalók}

A klaszterek pontosabb jellemzésére egyéb változókat is bevontam az elemzésbe. Az életkor, a nem, a projekttapasztalat és a projektben betöltött szerep változókat.

Az első klasztert alkotó projekttagok számára nem annyira fontos a határidők betartása, projektfeladatok megoldásához kevesebb tapasztalattal rendelkeznek, a feladatok megoldása kevésbé lelkesíti őket. Ebben a klaszterben vannak azok a projekttagok, akik a projekt munkájához pontos és megbízható munkájukkal járulnak hozzá.

A második klaszterben a határidők oszlopban eredményül kapott átlag értéke alapján megállapítható, hogy a csoportban lévők számára kiemelkedően fontos a határidők betartása. A csoportban résztvevők motivációjához tartozó átlag értéke nagyobb, mint a teljes átlag értéke. A tapasztalat szempont alapján elemezve szintén pozitív eredményt kapunk. Itt többségében tapasztalt, motivált, kiváló alkalmazottak vannak.

A harmadik klaszterben a határidők betartására vonatkozó elemzés szerint a csoport átlagának értéke kisebb, mint a teljes átlag. Ebbe a csoportba tartozók számára a legkisebb mértékben fontos a határidők betartása. Viszont a tapasztalat mértéke mind a teljes átlag értékénél, mind a csoportátlagok értékeinél magasabb. A motiváció mértéke az első és második klaszter értéke közé esik. Ebben a csoportban nagy tapasztalatú, de túltervezésre hajlamos alkalmazottakat találunk. Életkor szempontjából inkább középkorú férfi munkavállalók adták a válaszokat.

A késések és csúszások elfordulása megszokott számukra. A harmadik csoportba tartozó több éves projekttapasztalattal rendelkező projekttagok már kevésbé szentelnek kellő figyelmet a határidők betartásának. Fókuszukban a termék (létrehozása és paramétereinek fejlesztése) áll, inkább mérnöki szemlélettel rendelkeznek.

Az ideális projekt úgy múködne, hogy minden projekttag érdekelt a szervezeti célok megvalósításában, motivált, szem előtt tartja a kitűzött határidőket, azonban a gyakorlatban ez máshogy valósul meg. Az egyéni célnak összeegyeztethetőnek kell lennie a szervezeti célokkal a hatékony múködés érdekében. A szervezeti és az egyéni teljesítményértékelés összhangja fontos. Adottak a munkakörhöz szükséges kompetenciák: felelősségtudat, megbízhatóság, etikus magatartás. A szervezetek teljesítményértékelési rendszerének kiépítése rávilágított a hiányzó kompetenciákra. Teljesítményértékelés eredménye előléptetés, hiányzó kompetenciák pótlására irányuló soft skill képzések (például időmenedzsment), vagy a munkavégzéshez kötődő egyéni kompetenciák (hatékony munkavégzés a csapatban) fejlesztése.

A megkérdezettek 54\%-a tartozik abba a csoportba, akik betartják a határidőket, motiváltak a feladat elvégzésére és több éves projekttapasztalattal rendelkeznek. 


\section{TEMATIKUS TANULMÁNYOK - Menedzsment: vezetők, vezetés és munkavállalók}

\section{Összegzés}

Kutatásomban a projekttagok határidőhöz füződő viszonyát vizsgáltam. A versenyelőnyök folyamatosan változnak. Termékfejlesztési projektek esetében azonban a versenytársak műszaki fejlesztéseit megelőzve a vevők igényeinek gyorsabb felismerése, innovatívabb termékek létrehozása változatlanul kiemelt piaci előnyt jelent. Termékfejlesztési projekt sikere a projekt team összetételétől (motivált,- tapasztalt projekttagoktól) és a projekttagok időtényezőhöz fűződő viszonyától függ. A második klaszter projekttagjai számára a határidők betartása fontos, motiváltan látnak neki az elvégzendő feladatok végrehajtásának, és több éves projekttapasztalattal is rendelkeznek. A projekt hatékonyságát és eredményességét a második csoport tagjai határozzák meg. A projektben a projekttagok viselkedését figyelemmel követi a projektvezető. Előrelátó módon számolnia kell azzal, hogy különböző tapasztalatú, motivációjú és hozzáállású munkavállalók dolgoznak a projektben. A sikeres projektet a különbségek kiegyensúlyozására fel lehet építeni. Heterogén csoport létrehozásával hatékony munkát végeznek a projekttagok, szélsőséges csoportdinamikai hatásokat azonosítani és kezelni kell. Termékfejlesztési projektekbe olyan érintetteket célszerü a csoportba beosztani, akik kiegyensúlyozzák egyes fontos projekttagok hiányosságait, támogatják őket az új termékek megvalósításában. Egy-egy projektben az összes magatartástípus előfordulhat, mert az alkalmazottak különböző módon viszonyulnak a határidőkhöz. A szélsőséges halmozódásnál hangsúlyozom, hogy nem feltétlenül rossz szakemberekről van szó, hanem olyanokról, akik például hajlamosak túl precíz és aprólékos munkát végezni vagy hosszasan vitatják, hogy melyik megoldás lenne a helyesebb. A kiegyensúlyozott csoport ellenben túllép ezeken a vitákon és elkezdi megvalósítani a legkézenfekvőbb ötletet. Elősegíti ezt a folyamatot egy független mediátor alkalmazása vagy a projektvezető határozott iránymutatása. Örök érvényű igazság, hogy a jól működő kiválasztási folyamat szerepe fontos. Fokozottan igaz ez a projektekre, ahol időszakosan a napi rutin munkától hektikusabb állapotok fordulhatnak elő.

\section{Irodalom}

Bába É. - Berde Cs. (2010): Az idő, A XXI. század erőforrásáról vezetőknek. Szaktudás Kiadó Ház, Budapest

Bakacsi Gy. (2015): A szervezeti magatartás alapjai. Semmelweis Kiadó, Budapest

Berde Cs. - Móré M. (2014): A munkavállalói tudás hasznosításának új lehetősége

felsőoktatási keretek között. In: Vezetéstudomány 11. sz., Budapest

Chikán A. (2008): Vállalatgazdaságtan. Aula kiadó, Budapest

Dobák M. et al. (2014): A munkahelyi tanulás elősegítésének változásvezetési szempontjai. In: Magyar Tudomány, 175. évf. 12. sz. 
www. metszetek.unideb.hu

\section{TEMATIKUS TANULMÁNYOK - Menedzsment: vezetők, vezetés és munkavállalók}

Hunt, J. (1988): Managing People at Work. McGraw Hill, London

McClelland, D. C. (1985): Human Motivation. Scott, Foresman, Glenview, Illinois

Miller, J. G. - Roth A. V. (1994): A Taxonomy of Manufacturing Strategies. In: Management Science, Catonsville

Papp I. (2016): Elvárások és realitások a munka világában. In: Taylor Gazdálkodás és Szervezéstudományi folyóirat. Virtuális Intézet Közép-Európa Kutatására Közleményei. VIII. évf. 2. sz. No 23. Szeged.

Rappaport, J. (1981): In Praise of Paradox: A Social Policy of Empowerment Over Prevention. In: American Journal of Community Psychology, Vol 9, Illinois

Sajtos L. - Mitev, A. (2007): SPSS kutatási és adatelemzési kézikönyv. Alinea Kiadó, Budapest

Schumpeter, J. (2001, eredeti 1939): Konjunkturzyklen: Eine theoretische, historische und statistische Analyse des kapitalistischen Prozesses. Vandenhoeck Ruprecht Verlag, Göttingen

Szendi N. - Székely Cs. (2015): Analysis of Knowledge Sharing Process in Automotive Industry Projects. In: Gazdaság és Társadalom, Sopron 